\title{
Papaya Mealybug, Paracoccus marginatus Williams and Granara de Willink (Insecta: Hemiptera: Pseudococcidae) ${ }^{1}$
}

Alison Walker, Marjorie Hoy and Dale Meyerdirk²

\section{Introduction}

The papaya mealybug, Paracoccus marginatus Williams and Granara de Willink, is a small hemipteran that attacks several genera of host plants, including economically important tropical fruits and ornamentals. The papaya mealybug was discovered in Manatee and Palm Beach counties in Florida in 1998 and subsequently spread rapidly to several other Florida counties. It potentially poses a multi-million dollar threat to numerous agricultural products in Florida, as well as other states, if not controlled. Biological control was identified as a key component in a management strategy for the papaya mealybug, and a classical biological control program was initiated as a joint effort between the US Department of Agriculture, Puerto Rico Department of Agriculture, and Ministry of Agriculture in the Dominican Republic in 1999.

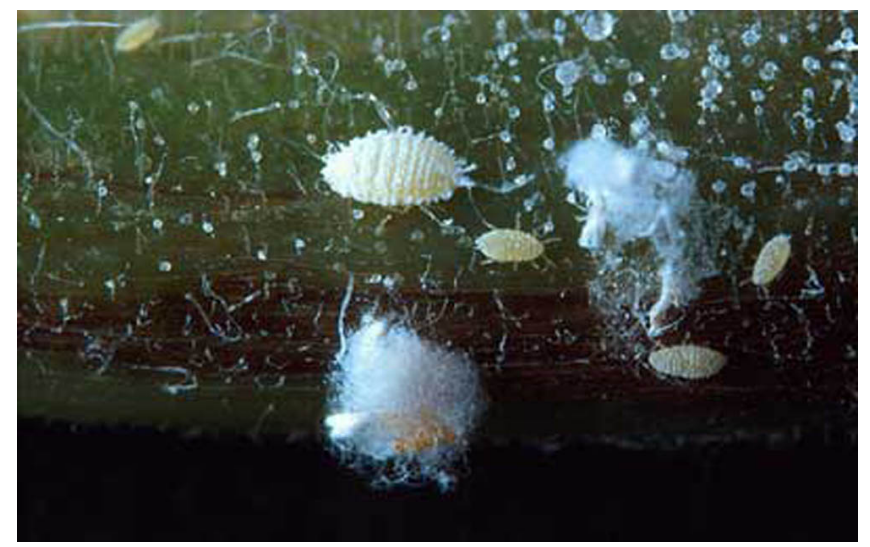

Figure 1. Adults and egg sacs of papaya mealybug, Paracoccus marginatus Williams and Granara de Willink. Credits: Dale Meyerdirk, National Biological Control Institute

\section{Distribution}

The papaya mealybug is believed to be native to Mexico and/or Central America. It has never gained status as a serious pest there, probably due to the presence of an endemic natural enemy complex. The first specimens were collected in Mexico in 1955. The papaya mealybug was described in 1992 from the

1. This document is EENY-302, one of a series of Featured Creatures from the Entomology and Nematology Department, Florida Cooperative Extension Service, Institute of Food and Agricultural Sciences, University of Florida. Published: August 2003. This document is also available on Featured Creatures Website at http://creatures.ifas.ufl.edu. Please visit the EDIS Website at http://edis.ifas.ufl.edu. Additional information on these organisms, including many color photographs, is available at the Entomology and Nematology Department website at http://entnemdept.ifas.ufl.edu/.

2. Alison Walker and Marjorie Hoy, Department of Entomology and Nematology, Institute of Food and Agricultural Sciences, University of Florida, Gainesville, and Dale Meyerdirk, National Biological Control Institute.

The Institute of Food and Agricultural Sciences (IFAS) is an Equal Employment Opportunity - Affirmative Action Employer authorized to provide research, educational information and other services only to individuals and institutions that function without regard to race, creed, color, religion, age, disability, sex, sexual orientation, marital status, national origin, political opinions or affiliations. For information on obtaining other extension publications, contact your county Cooperative Extension Service office. Florida Cooperative Extension Service / Institute of Food and Agricultural Sciences / University of Florida / Larry R. Arrington, Interim Dean 
Neotropical Region in Belize, Costa Rica, Guatemala, and Mexico (Williams and Granara de Willink 1992). When the papaya mealybug invaded the Caribbean region, it became a pest there; since 1994 it has been recorded in the following 14 Caribbean countries: St. Martin, Guadeloupe, St. Barthelemy, Antigua, Bahamas, British Virgin Islands, Cuba, Dominican Republic, Haiti, Puerto Rico, Montserrat, Nevis, St. Kitts, and the U.S. Virgin Islands. More recently, specimens have turned up in the Pacific regions of Guam and the Republic of Palau. mealybug could rapidly establish throughout Florida and through the Gulf states to California. It is possible that certain greenhouse crops could be at risk in areas as far north as Delaware, New Jersey and Maryland. It has already been identified on papaya plants in the Garfield Conservatory in Chicago, Illinois in late August of 2001. A biological control program was implemented in December of 2001 with very successful results.

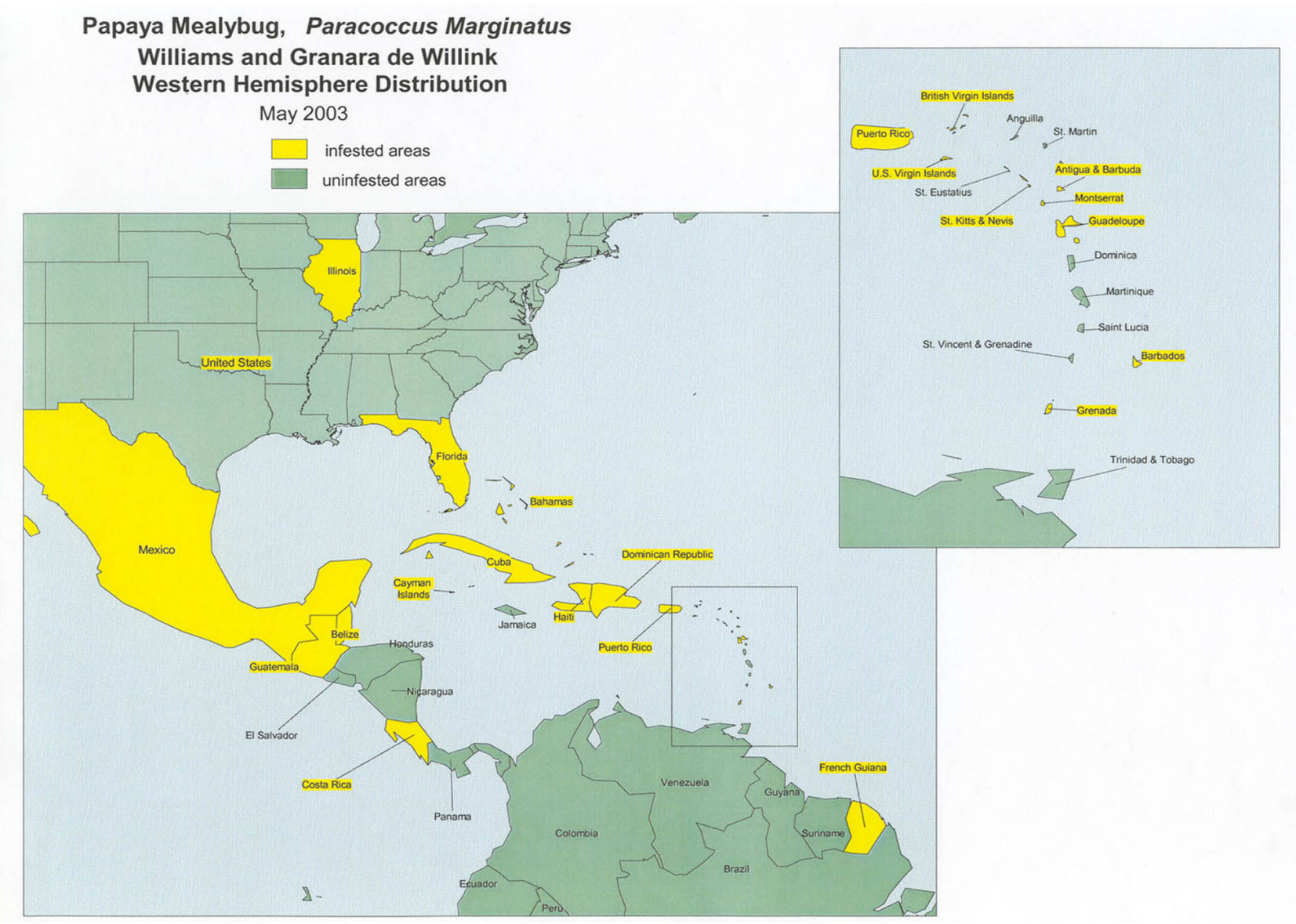

Figure 2. Distribution of the papaya mealybug, Paracoccus marginatus Williams and Granara de Willink, as of May 2003. Credits: Dale Meyerdirk, National Biological Control Institute

The papaya mealybug was discovered in Bradenton, Florida in 1998 on hibiscus. By January 2002, it had been collected 80 times on 18 different plant species in 30 cities throughout Alachua, Brevard, Broward, Collier, Dade, Hillsborough, Manatee, Martin, Monroe, Palm Beach, Pinellas, Polk, Sarasota, and Volusia counties.

Specimens also have been intercepted in Texas and California, and it is expected that papaya

\section{Description}

Papaya mealybug infestations are typically observed as clusters of cotton-like masses on the above-ground portion of plants. The adult female is yellow and is covered with a white waxy coating. Adult females are approximately $2.2 \mathrm{~mm}$ long (1/16 inch) and $1.4 \mathrm{~mm}$ wide. A series of short waxy caudal filaments less than 1/4 the length of the body exist around the margin. 


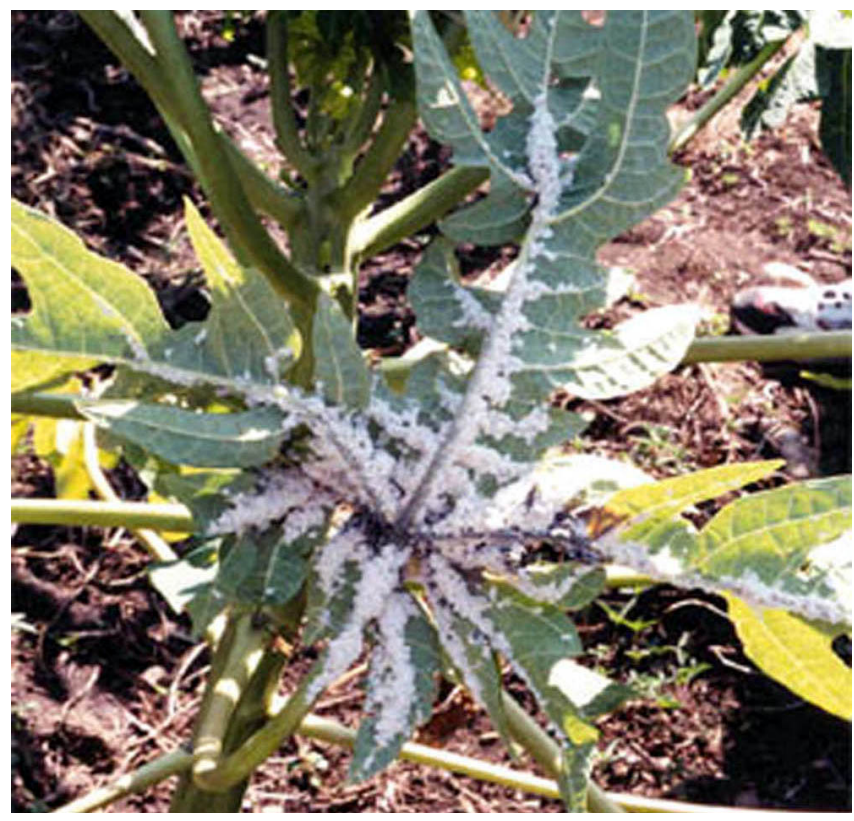

Figure 3. Papaya leaf infestation of the papaya mealybug, Paracoccus marginatus Williams and Granara de Willink. Credits: Dale Meyerdirk, National Biological Control Institute

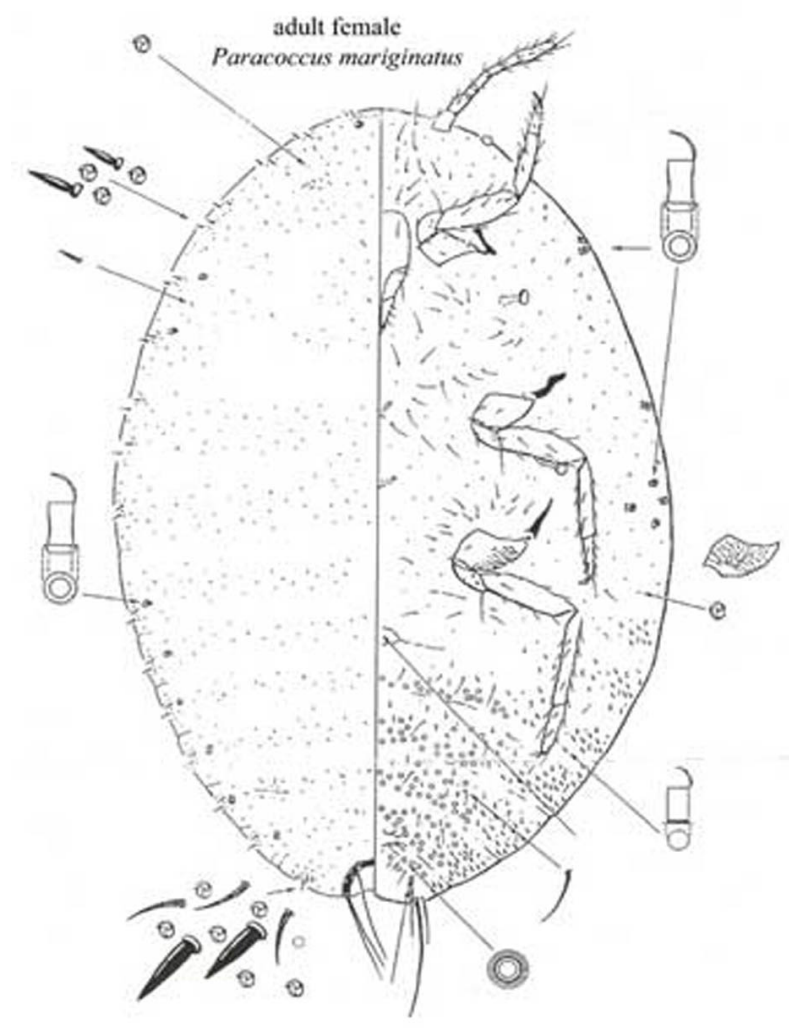

Figure 4. Adult female papaya mealybug, Paracoccus marginatus Williams and Granara de Willink. Credits: D. Miller and G. Miller, USDA

Eggs are greenish yellow and are laid in an egg sac that is three to four times the body length and entirely covered with white wax. The ovisac is developed ventrally on the adult female.
Adult males tend to be colored pink, especially during the pre-pupal and pupal stages, but appear yellow in the first and second instar. Adult males are approximately $1.0 \mathrm{~mm}$ long, with an elongate oval body that is widest at the thorax $(0.3 \mathrm{~mm})$. Adult males have ten-segmented antennae, a distinct aedeagus, lateral pore clusters, a heavily sclerotized thorax and head, and well-developed wings.

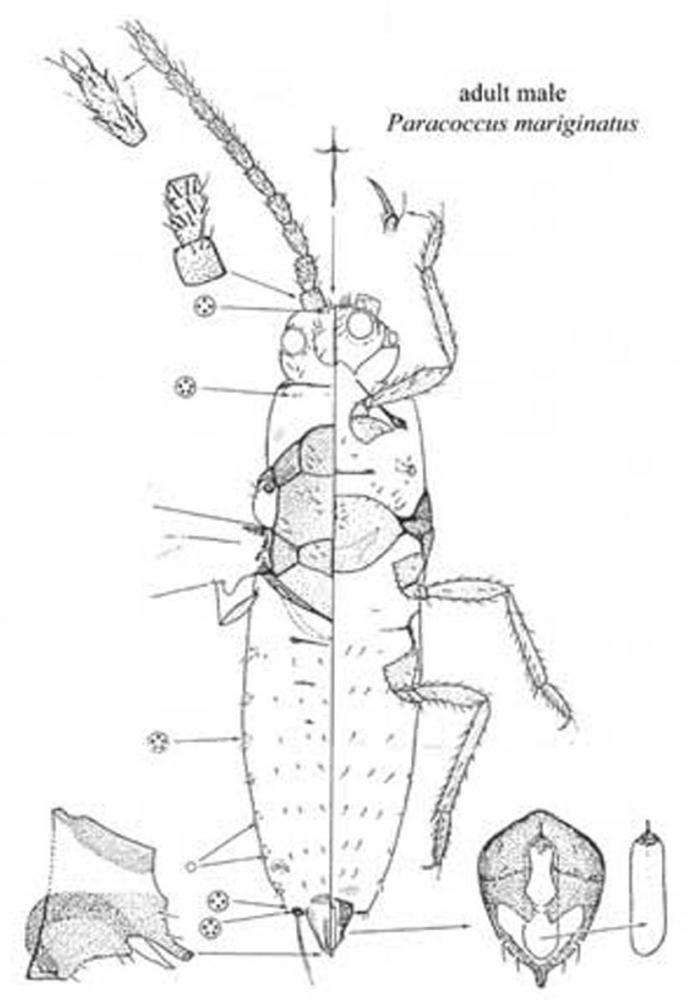

Figure 5. Adult male papaya mealybug, Paracoccus marginatus Williams and Granara de Willink. Credits: D. Miller and G. Miller, USDA

Miller and Miller (2002) give a complete description of all instars of both sexes of the papaya mealybug, as well as a complete description of characters used to distinguish the papaya mealybug from other closely related species. Two characteristics that are important in distinguishing P. marginatus adult females from all other species of Paracoccus are: the presence of oral-rim tubular ducts dorsally restricted to marginal areas of the body, and the absence of pores on the hind tibiae. Adult males may be distinguished from other related species by the presence of stout fleshy setae on the antennae and the absence of fleshy setae on the legs. 
The papaya mealybug can easily be distinguished from Maconellicoccus marginatus (Green), the pink hibiscus mealybug, because papaya mealybug females have eight antennal segments, in contrast to nine in the latter species.

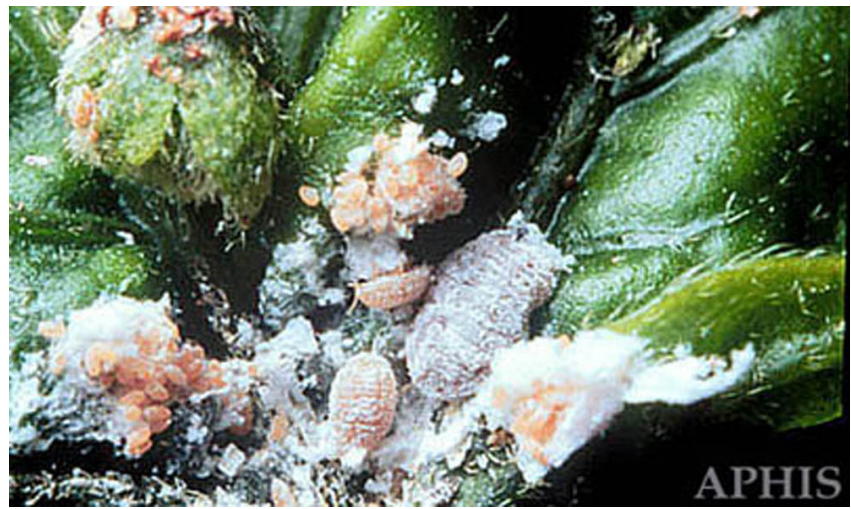

Figure 6. Various stages in the life cycle of the pink hibiscus mealybug, Maconellicoccus hirsutus (Green). Credits: Dale Meyerdirk, National Biological Control Institute

Specimens of papaya mealybug turn bluish-black when placed in alcohol, as is characteristic of other members of this genus.

\section{Biology}

Details on the biology and life cycle of the papaya mealybug are lacking. In general, mealybugs have piercing-sucking mouthparts and feed by inserting their mouthparts into plant tissue and sucking out sap. Mealybugs are most active in warm, dry weather. Females have no wings, and move by crawling short distances or by being blown in air currents. Females usually lay 100 to 600 eggs in an ovisac, although some species of mealybugs give birth to live young. Egg-laying usually occurs over the period of one to two weeks. Egg hatch occurs in about 10 days, and nymphs, or crawlers, begin to actively search for feeding sites. Female crawlers have four instars, with a generation taking approximately one month to complete, depending on the temperature. Males have five instars, the fourth of which is produced in a cocoon and referred to as the pupa. The fifth instar of the male is the only winged form of the species capable of flight. Adult females attract the males with sex pheromones. Under greenhouse conditions, reproduction occurs throughout the year, and in certain species may occur without fertilization.

\section{Host Plants}

The papaya mealybug is polyphagous and has been recorded on $>55$ host plants in more than 25 genera. Economically important host plants of the papaya mealybug include papaya, hibiscus, avocado, citrus, cotton, tomato, eggplant, peppers, beans and peas, sweet potato, mango, cherry, and pomegranate.

\section{Damage}

The papaya mealybug feeds on the sap of plants by inserting its stylets into the epidermis of the leaf, as well as into the fruit and stem. In doing so, it injects a toxic substance into the leaves. The result is chlorosis, plant stunting, leaf deformation, early leaf and fruit drop, a heavy buildup of honeydew, and death. Heavy infestations are capable of rendering fruit inedible due to the buildup of thick white wax. Papaya mealybug has only been recorded feeding on areas of the host plant that are above ground, namely the leaves and fruit.

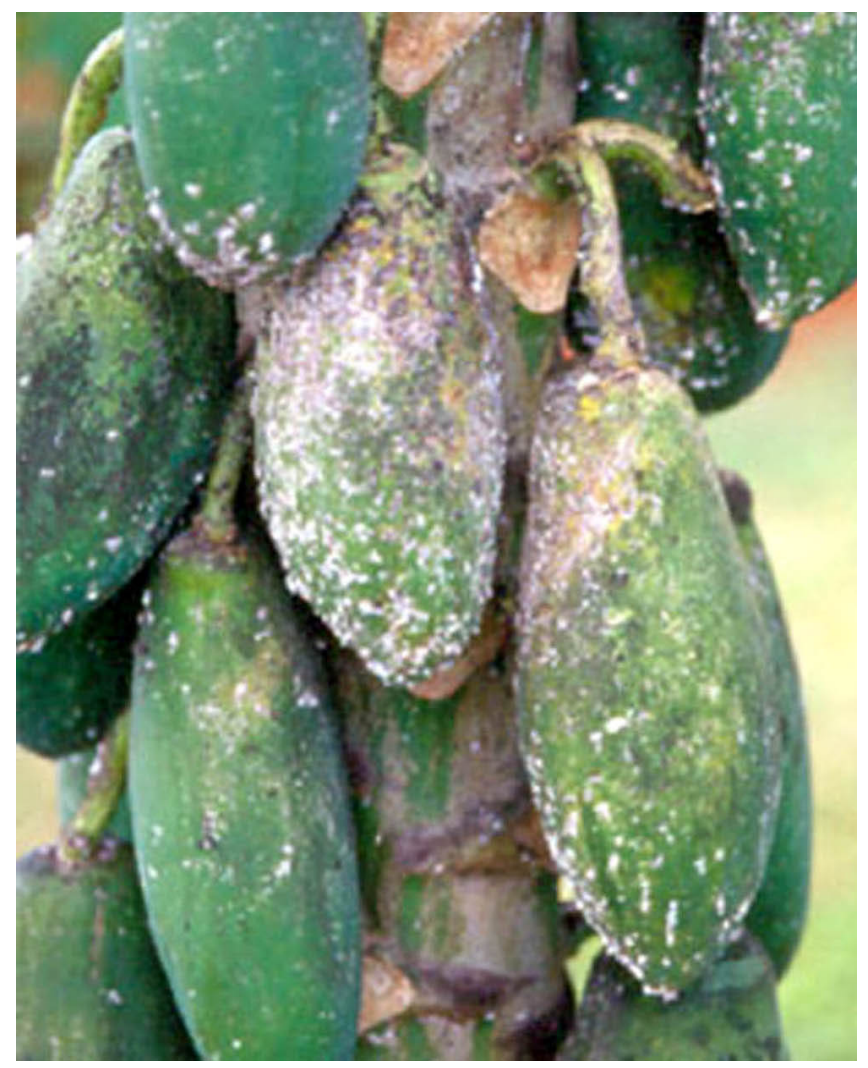

Figure 7. Papaya fruit infestation and damage caused by the papaya mealybug, Paracoccus marginatus Williams and Granara de Willink. Credits: Dale Meyerdirk, National Biological Control Institute 


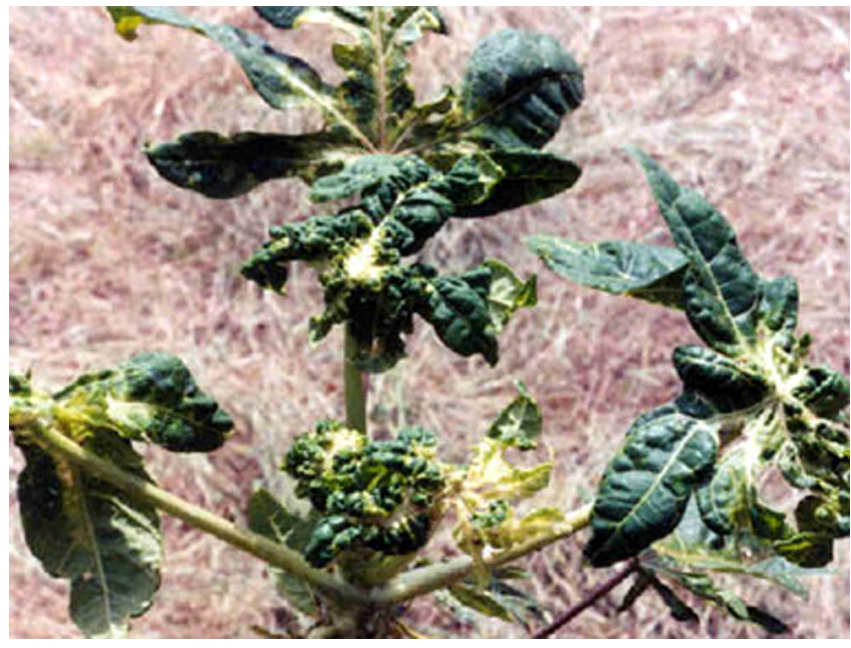

Figure 8. Papaya leaf deformation caused by the papaya mealybug, Paracoccus marginatus Williams and Granara de Willink. Credits: Dale Meyerdirk, National Biological Control Institute

\section{Management}

Chemical control: A number of chemical controls are available to control mealybugs, although none are currently registered specifically for control of papaya mealybug. Active ingredients in registered pesticide formulations include acephate, carbaryl, chlorpyrifos, diazinon, dimethoate, malathion, and white mineral oils. Typically, twice the normal dose is applied when treating for mealybugs because mealybugs are protected by thick waxy, cottony sacs, and often are concealed inside damaged leaves and buds. Thus, chemical controls are only partially effective and require multiple applications. Furthermore, problems with insecticide resistance and non-target effects on natural enemies make chemical control a less desirable control option to combat the papaya mealybug.

Biological control: Natural enemies of the papaya mealybug include the commercially available mealybug destroyer (Cryptolaemus montrouzieri), lady beetles, lacewings, and hover flies, all which are generalist predators that have a potential impact on mealybug populations. In addition to predators, several parasitoids may attack papaya mealybug.

In 1999, the USDA Animal and Plant Health Inspection Service (APHIS) and USDA Agricultural Research Service (ARS) initiated a classical biological control program for the papaya mealybug. Four genera of encyrtid endoparasitoid wasps specific to mealybugs were collected in Mexico by USDA and ARS researchers and Mexican cooperators as potential biological control agents: Acerophagus papayae (Noyes and Schauff), Anagyrus loecki (Noyes and Menezes), Anagyrus californicus Compere, and Pseudaphycus sp. (USDA 1999, 2000; Meyerdirk and Kauffman 2001). A fifth collected species was later reared and identified as Pseudleptomastix mexicana (Noyes and Schauff 2003).

All four species were screened in USDA/ARS quarantine facilities in Newark, Delaware and environmental assessments were completed (USDA-APHIS 1999, 2000, 2002). Specimens were then shipped to Puerto Rico where they were cultured and mass-reared for experimental release in Puerto Rico and the Dominican Republic. The first releases of these four parasitoids were made in Florida in October 2000.

To date, APHIS has found that the release of the four genera of parasitoid wasps has brought a $99.7 \%$ reduction in the density of mealybug populations at research sites in the Dominican Republic, and a 97\% reduction at research sites in Puerto Rico, with parasitism levels between $35.5 \%$ and $58.3 \%$ (Kauffman et al. 2001, Meyerdirk and Kauffman 2001). All four species of parasitoids have been observed attacking second and third instars of $P$. marginatus. However, Acerophagus sp. emerged as the dominant parasitoid species in both Puerto Rico and the Dominican Republic (Meyerdirk and Kauffman 2001). The outcome of releases of the four parasitoids in Florida is yet to be determined as of March 2003.

\section{Selected References}

Becker H. 2000. Three imported wasps may curb scale pest. Agricultural Research, May 2000, p. 16-17.

Eversole C. (March 1999). Search for pest turns up dangerous cousin, UF researcher says. University of Florida News Release. http://www.napa.ufl.edu/99news/papaya.htm (21 August 2002). 
Kauffman WC, Meyerdirk DE, Miller D, Schauff M, Hernandez HG, Villanueva Jimenez JA. 2001. Papaya mealybug biological control in Puerto Rico and Dominican Republic. Presented 11 December 2001 at the ESA Annual Meeting, San Diego, CA.

Kauffman WC, Meyerdirk DE, Warkentin R. Biological control of papaya mealybug in the Caribbean Safeguarding the U.S. Presented 2-4 August 2001 at the IOBC meeting, Bozeman, MT.

Martinez M, Moraima S, Perez I. 2000. Second Mealybug Invader. CABI - Biocontrol News and Information 21 (2).

McKenzie H. 1967. Mealybugs of California with Taxonomy, Biology, and Control of North American Species (Homoptera: Coccoidae: Pseudococcidae). University of California Press, Berkeley.

Meyerdirk DE, Kauffman WC. 2001. Status on the development of a biological control program for Paracoccus marginatus Williams, papaya mealybug. Internal USDA, APHIS, PPQ Report.

Miller DR, Miller GL. 2000. Taxonomic information on Paracoccus marginatus. Technical Meeting and Workshop for the Biological Control of the Papaya Mealybug, Paracoccus marginatus, in the Caribbean. St. Kitts, West Indies, 25-26 July 2000.

Miller DR, Miller GL. 2002. Redescription of Paracoccus marginatus Williams and Granara de Willink (Hemiptera: Coccoidea: Pseudococcidae), including descriptions of the immature stages and adult male. Proceedings of the Entomological Society of Washington 104: 1-23.

Miller DR, Williams DJ, Hamon AB. 1999. Notes on a new mealybug (Hemiptera: Coccoidea: Pseudococcidae) pest in Florida and the Caribbean: the papaya mealybug, Paracoccus marginatus Williams and Granara de Willink. Insecta Mundi 13: (3-4).

Nguyen R. (10 October 2002). Crawford announces new biological control of plant pest. FDOACS Agriculture Press Release. http://www.doacs.state.fl.us/press/2000/ 10102000.html (20 June 2003).

New Pest Advisory Group. 1998. NPAG Report File \#98 (unpublished). U.S. Department of Agriculture, Animal and Plant Health Inspection Service, Plant Protection and Quarantine, NPAG, Riverdale, MD. 11 p.

Noyes JS, Hayat M. 1994. Oriental Mealybug Parasitoids of the Anagyrini (Hymenoptera: Encyrtidae). CAB International, UK. 554 pp.

Noyes JS, Schauff ME. 2003. New Encyrtidae (Hymenoptera) from Papaya Mealybug (Paracoccus marginatus Williams and Granara de Willink) (Hemiptera: Sternorrhyncha: Pseudococcidae). Proceedings of the Entomological Society of Washington 105: 180-185.

Osborne, LS. (19 September 2002). Mealybugs. http://www.mrec.ifas.ufl.edu/lso/mealybugs.htm (20 June 2003).

Schauff ME, Gates M. 2002. Parasitoids of the papaya mealybug (Paracoccus marginatus). EC Cariforum, Caribbean Agriculture and Fisheries Program, "Regional Training Workshop on Management of Papaya Mealybug". San Juan, Puerto Rico, 23-25 October 2002.

Watson GW, Chandler LR. 1999. Identification of Mealybugs Important in the Caribbean Region. Commonwealth Science Council and CAB International, London. $40 \mathrm{pp}$.

Williams DJ, Granara de Willink MC. 1992. Mealybugs of Central and South America. CAB International, UK, 644 pp.

U.S. Department of Agriculture, Animal and Plant Health Inspection Service. 1999. Control of the papaya mealybug, Paracoccus marginatus (Homoptera: Pseudococcidae). Environmental Assessment, October 1999. Riverdale, MD.

U.S. Department of Agriculture, Animal and Plant Health Inspection Service. 2000. Control of the papaya mealybug, Paracoccus marginatus (Homoptera: Pseudococcidae). Environmental 
Assessment (Supplement), June 2000. Riverdale, MD.

U.S. Department of Agriculture, Animal and Plant Health Inspection Service. 2002. Control of the papaya mealybug, Paracoccus marginatus (Homoptera: Pseudococcidae). Environmental Assessment, June 2002. Riverdale, MD. 